\title{
STUDIES OF THE DIPYRRYLMETHENE ("FUSCIN") PIGMENTS. II. THE CONTRASTING RATIOS AND SIGNIFICANCE OF THE FECAL UROBILINOGEN AND MESOBILIFUSCIN IN CERTAIN ANEMIAS *
}

\author{
By A. SIGRID GILBERTSEN, VIOLET HAWKINSON AND C. J. WATSON \\ (From the Department of Medicine, University of Minnesota Hospital, Minneapolis, Minn.)
}

(Submitted for publication September 15, 1958; accepted March 12, 1959)

In the preceding communication (1) evidence was described indicating that the fecal dipyrrylmethene or "fuscin" compounds are derived mainly from anabolic sequences on the pathway to heme, rather than oxidative schism of tetrapyrryl bilirubinoids from destroyed hemoglobin. Using $\mathrm{N}^{15}$ glycine, it was shown that $\mathrm{N}^{15}$ was rapidly incorporated in mesobilifuscin (Mbf) with production of an early peak and that there was little or no significant concentration of $\mathrm{N}^{15}$ in $\mathrm{Mbf}$ at the time of destruction of mature circulating erythrocytes when the stercobilin $\mathrm{N}^{15}$ was greatly elevated. It is recognized, however, that under appropriate conditions $\mathrm{Mbf}$ is derived by oxidation of bilirubinoid compounds and that minor fractions of the dipyrrylmethene group in the excreta may originate in this fashion. Under normal conditions the feces contain chromogens and pigments of both anabolic and catabolic origin, i.e., compounds of mesobilifuscin(ogen) type elaborated principally during heme synthesis, and urobilinogen derived, at least mainly, from hemoglobin destruction. It would be anticipated, therefore, that the amount of fecal Mbf as compared with urobilinogen might vary significantly in differing hematologic disorders.

The present study was undertaken to compare the excretion of mesobilifuscin and urobilinogen in the feces of normal subjects and in patients with various anemias.

\section{MATERIALS AND METHODS}

A total of 140 individuals were studied. Of these, 19 were normal subjects, either medical or nursing students or hospital personnel. The remainder comprised 32 patients with hemolytic anemia, four with megaloblastic anemia, nine with hyporegenerative anemia, nine with anemia due to rheumatoid disease, 27 with anemia

* Aided under contracts with the Surgeon-General's Office, United States Army. due to various other causes including infection, uremia, iron deficiency, cancer and refractory anemia, 20 with parenchymal liver disease including cirrhosis and hepatitis and 20 with obstructive biliary tract disease.

Collections of feces were made over four or eight day periods in the majority of instances, although in 44 , as will be indicated, random or short period samples were analyzed for urobilinogen and mesobilifuscin. Where the four day collection was adequate (at least $350 \mathrm{Gm}$.) the per diem amount was calculated; otherwise the values are given in $\mathrm{mg}$. per $100 \mathrm{Gm}$. Urobilinogen was determined by the method of Schwartz, Sborov and Watson (2). After extraction of the urobilinogen from the initial acidified filtrate, the latter was used for determination of Mbf. The method was the modification of Siedel and Möller's procedure ( 3 ) described in the preceding paper for isolation of $\mathrm{Mbf}$. Following elution of the methyl ester from the $\mathrm{Al}_{2} \mathrm{O}_{3}$ column, the hot glacial acetic acid eluate was filtered and diluted. The optical density of this solution was then determined in the Evelyn colorimeter using a 490 filter. The standard was prepared from mesobilirubinogen by oxidation with lead tetraacetate as described by Siedel and Möller (3). In the preceding paper of this series it was shown that the fecal pigment obtained with this method corresponds fully with Siedel and Möller's fecal mesobilifuscin in terms of solubility and chromatographic behavior, spectral characteristics, nitrogen percentage and products of oxidative degradation. For purposes of determining the reproducibility of results with this method, multiple analyses for Mbf were performed by different technicians on fecal samples from six subjects (Table $I$ ). The individual variation in urobilinogen and Mbf excretion was examined by analyses of multiple four day samples in 15 subjects, multiple short period samples in three subjects and four day samples followed by one or more short period samples in three subjects (see under Results).

Red blood cell survival was studied in 43 cases using $\mathrm{Cr}^{61}$ according to the ascorbic acid modification (4) of the usual method (5-7). Sternal bone marrow aspiration studies were performed in 52 cases. $^{1}$ Bone marrow studies were not performed in any of the normal subjects;

${ }^{1}$ Carried out in the Special Hematology Laboratory at the University of Minnesota Hospital. We acknowledge gratefully the cooperation of Dr. R. Dorothy Sundberg and her associates in the bone marrow studies. 
TABLE I

Reliability of method for determination of mesobilifuscin as revealed by repeated analyses of the same samples of

feces by different technicians (six samples, two to six analyses of each)

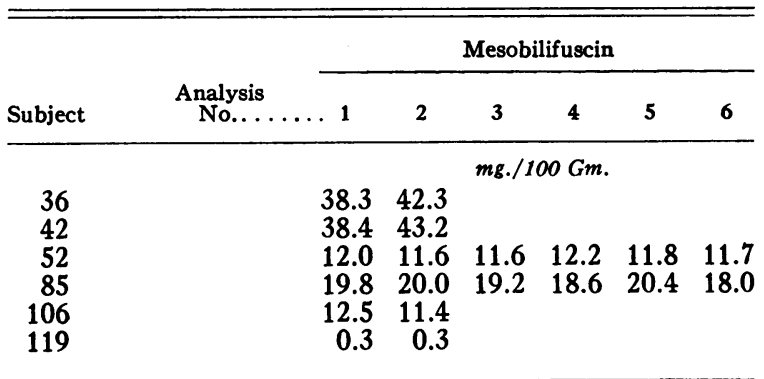

the normal values had been well established previously (8).

Twenty-four hour urine collections were made in seven of the normal subjects and in 11 patients with parenchy- mal liver disease. The amount of urobilinogen in these samples was determined by the above-mentioned method (2). Another aliquot of the same urine sample was used for the determination of mesobilifuscin. The urine was first acidified with glacial acetic acid to $\mathrm{pH} 5$ petroleum ether to remove all, or nearly all, of the urobilinogen. The unheated aqueous fraction was then extracted twice with approximately $75 \mathrm{ml}$. of butyl alcohol. From this point the method was identical with that described above for feces. The presence or absence of bilirubin was determined by the Harrison strip test (9). In two cases the urine bilirubin was quantitated by the method of Malloy and Evelyn (10).

\section{RESULTS}

The values obtained for fecal urobilinogen, fecal mesobilifuscin, the urobilinogen/mesobilifuscin ( $\mathrm{U} / \mathrm{Mbf}$ ) ratio, the $\mathrm{T}_{1 / 2}$ of $\mathrm{Cr}^{51}$ and the myeloiderythroid volume and percentage of normoblasts

TABLE II

Urobilinogen and mesobilifuscin in the feces, $U / M b f$ ratio and erythrocyte survival in 19 normal subjects

\begin{tabular}{|c|c|c|c|c|c|c|}
\hline \multirow[b]{2}{*}{ Subject } & \multirow[b]{2}{*}{ Sex } & \multirow[b]{2}{*}{ Age } & \multicolumn{3}{|c|}{ Feces } & \multirow[b]{2}{*}{$\mathrm{T}_{1} \mathrm{Cr}^{51}$} \\
\hline & & & Urobilinogen & Mesobilifuscin & $\mathrm{U} / \mathrm{Mbf}$ & \\
\hline & & & $\begin{array}{c}m g . / d a y \\
\text { or } \\
m g . / 100 \mathrm{Gm} . *\end{array}$ & $\begin{array}{c}m g . / d a y \\
\text { or } \\
m g . / 100 \mathrm{Gm} . *\end{array}$ & & days \\
\hline 1 & $\mathbf{M}$ & 24 & 197 & 17.5 & 11.3 & 27.0 \\
\hline 2 & $\mathbf{M}$ & 24 & $150\left\{\begin{array}{l}175 \dagger \\
125\end{array}\right.$ & $13.2\left\{\begin{array}{l}15.8 \\
10.5\end{array}\right.$ & $11.4\left\{\begin{array}{l}11.0 \\
12.1\end{array}\right.$ & 29.5 \\
\hline 3 & $\mathbf{M}$ & 22 & $133\left\{\begin{array}{l}146 \\
119\end{array}\right.$ & $12.2\left\{\begin{array}{r}14.5 \\
9.9\end{array}\right.$ & $10.9\left\{\begin{array}{l}10.0 \\
11.9\end{array}\right.$ & 25.0 \\
\hline 4 & $\mathbf{M}$ & 28 & $111\left\{\begin{array}{r}124 \\
98\end{array}\right.$ & $8.3\left\{\begin{array}{l}8.8 \\
7.8\end{array}\right.$ & $13.4\left\{\begin{array}{r}9.2 \\
10.0\end{array}\right.$ & 26.0 \\
\hline 5 & $\mathbf{M}$ & 22 & $153\left\{\begin{array}{l}161 \\
145\end{array}\right.$ & $12.9\left\{\begin{array}{l}12.4 \\
13.4\end{array}\right.$ & $11.9\left\{\begin{array}{l}13.0 \\
10.8\end{array}\right.$ & 26.5 \\
\hline 6 & $\mathrm{~F}$ & 27 & $\begin{array}{l}87 \\
110^{*} \\
78^{*}\end{array}$ & $\begin{array}{l}10.5 \\
13.1^{*} \\
9.8^{*}\end{array}$ & $\begin{array}{l}8.2 \\
8.5 \\
8.0\end{array}$ & 26.0 \\
\hline 7 & $\mathrm{~F}$ & 23 & $149\left\{\begin{array}{l}140 \\
158\end{array}\right.$ & $16.1\left\{\begin{array}{l}16.0 \\
16.2\end{array}\right.$ & $9.2\left\{\begin{array}{l}8.7 \\
9.7\end{array}\right.$ & 28.0 \\
\hline $\begin{array}{l}8 \\
9\end{array}$ & $\mathbf{F}$ & $\begin{array}{l}21 \\
20\end{array}$ & $\begin{array}{c}93 \\
70 \\
104^{*}\end{array}$ & $\begin{array}{c}7.5 \\
7.4 \\
12.0^{*}\end{array}$ & $\begin{array}{r}12.4 \\
9.3 \\
8.7\end{array}$ & $\begin{array}{l}28.0 \\
25.0\end{array}$ \\
\hline $\begin{array}{l}10 \\
11\end{array}$ & $\mathrm{~F}$ & $\begin{array}{l}21 \\
20\end{array}$ & $\begin{array}{r}149 \\
83\end{array}$ & $\begin{array}{r}11.8 \\
7.7\end{array}$ & $\begin{array}{l}12.6 \\
10.8\end{array}$ & $\begin{array}{l}26.5 \\
27.0\end{array}$ \\
\hline 12 & $\mathrm{~F}$ & 28 & $99\left\{\begin{array}{r}74 \\
118\end{array}\right.$ & $7.3\left\{\begin{array}{l}6.0 \\
8.3\end{array}\right.$ & $13.6\left\{\begin{array}{l}12.3 \\
14.2\end{array}\right.$ & \\
\hline $\begin{array}{l}13 \\
14 \\
15 \\
16 \\
17 \\
18 \\
19\end{array}$ & $\begin{array}{l}\mathrm{M} \\
\mathbf{M} \\
\mathbf{M} \\
\mathbf{M} \\
\mathbf{F} \\
\mathbf{F} \\
\mathbf{M}\end{array}$ & $\begin{array}{l}29 \\
38\end{array}$ & $\begin{array}{c}92 \\
110^{*} \\
92^{*} \\
138^{*} \\
88^{*} \\
72^{*} \\
70^{*}\end{array}$ & $\begin{array}{r}9.0^{*} \\
9.0^{*} \\
8.1^{*} \\
12.5^{*} \\
8.5^{*} \\
6.5^{*} \\
7.2^{*}\end{array}$ & $\begin{array}{r}10.2 \\
12.2 \\
11.3 \\
11.0 \\
10.3 \\
11.1 \\
9.7\end{array}$ & \\
\hline $\begin{array}{l}\text { Norn } \\
\text { Mear }\end{array}$ & $\begin{array}{l}\text { e } \\
\text { anda }\end{array}$ & tion & $\begin{array}{c}70-197 \\
120 \pm 37.4\end{array}$ & $\begin{array}{c}7.3-17.5 \\
10.9 \pm 3.42\end{array}$ & $\begin{array}{c}8.2-14.2 \\
11.1 \pm 1.44\end{array}$ & $25-29.5$ \\
\hline
\end{tabular}

* Numbers indicated by an asterisk denote quantitations in $\mathrm{mg}$. per $100 \mathrm{Gm}$.; numbers without an asterisk denote quantitations in $\mathrm{mg}$. per day.

† The determinations in brackets relate to separate samples either random, as indicated by the asterisks, or four day collections, the average being given at the left in each instance. 
in concentrated smears of the sternal bone marrow, in each of 19 normal subjects and in 121 patients with anemia are shown in Tables II through VII. The ranges of the per diem excretion of $\mathrm{Mbf}$ (in those cases where feces collections were adequate) and the $\mathrm{U} / \mathrm{Mbf}$ ratios in 19 normal subjects and 94 patients with anemia (those cases of which there are sufficient numbers to classify) are represented graphically in Figure
1. In the group of normal subjects (Table II) the average daily excretion of urobilinogen was lower than previously reported from this laboratory (11). This may be explained, at least in part, by the inclusion of a greater number of female subjects in whom the red cell mass and, consequently, the urobilinogen excretion are normally less than in the male. The average daily excretion of $\mathrm{Mbf}$ and the $\mathrm{U} / \mathrm{Mbf}$ ratio ranged, respectively, from

TABLE III

Urobilinogen and mesobilifuscin in the feces, $U / M b f$ ratio, erythrocyte survival and erythropoiesis in 32 patients with hemolytic anemia

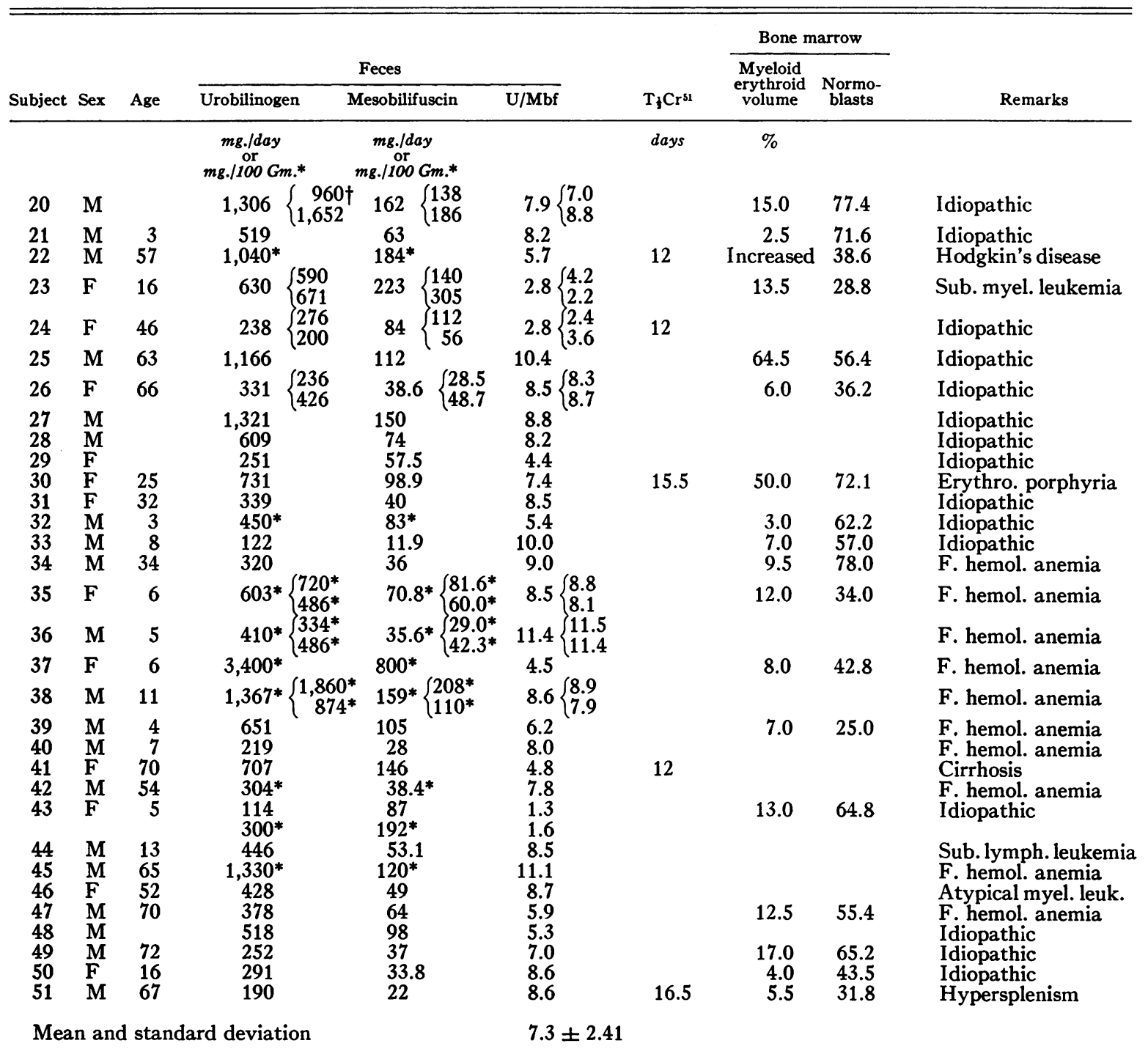

* Numbers indicated by an asterisk denote quantitations in $\mathrm{mg}$. per $100 \mathrm{Gm}$.; numbers without an asterisk denote quantitations in $\mathrm{mg}$. per day.

$\dagger$ The values in brackets relate to separate samples, either random, as indicated by asterisks, or four day collections, the average shown at the left. 
7.3 to $17.5 \mathrm{mg}$. per day and from 8.2 to 14.2 . Moderate variations in the quantities of urobilinogen and $\mathrm{Mbf}$ excreted in consecutive four day or short period samples in eight normal subjects (Table II) and thirteen patients (Tables III through VI) are seen. However, the U/Mbf ratio remained relatively constant in a given individual, varying no more than 2.2 in 20 of 21 subjects with multiple determinations. The one exception (Case 60) will be considered again in the following.

The $\mathrm{T}_{1 / 2}$ of $\mathrm{Cr}^{51}$ of 25 to 29.5 days in the normal subjects (Table II) agrees with previous reports using the same method (12). The myeloiderythroid volume in the bone marrow ranges from 5 to 8 per cent normally, and the normal percent- age of normoblasts is considered to be approximately 20 (8).

A sharp contrast to the findings in normal subjects is seen in patients with hemolytic anemia (Table III and Figure 1). In most of these cases the fecal urobilinogen was elevated; however, in eight of 32 patients the urobilinogen was less than $300 \mathrm{mg}$. per day. In the latter cases the hemoglobin levels were considerably decreased; when urobilinogen values were calculated in relation to the total circulating hemoglobin as "apparent wastage" $(13,14)$, they were found to be significantly elevated. It should be noted that three of these latter cases (Nos. 33, 40 and 43) were anemic children, aged five to eight, in whom the total circulating hemoglobin values were quite

TABLE IV

Urobilinogen and mesobilifuscin in the feces, $U / M b f$ ratio, erythrocyte survival and erythropoiesis in anemia

\begin{tabular}{|c|c|c|c|c|c|c|c|c|c|}
\hline \multirow[b]{3}{*}{ Subject } & \multirow[b]{3}{*}{ Sex } & \multirow[b]{3}{*}{ Age } & \multirow{2}{*}{\multicolumn{3}{|c|}{ Feces }} & \multirow[b]{3}{*}{$\mathrm{T}_{3} \mathrm{Cr}^{31}$} & \multicolumn{2}{|c|}{ Bone marrow } & \multirow[b]{3}{*}{ Remarks } \\
\hline & & & & & & & \multirow{2}{*}{$\begin{array}{c}\text { Myeloid } \\
\text { erythroid } \\
\text { volume }\end{array}$} & \multirow{2}{*}{$\begin{array}{c}\text { Normo- } \\
\text { blasts }\end{array}$} & \\
\hline & & & Urobilinogen & Mesobilifuscin & $\mathrm{U} / \mathrm{Mbf}$ & & & & \\
\hline & & & $\begin{array}{c}m g . / \text { day } \\
\text { or } \\
m g . / 100 \mathrm{Gm} . *\end{array}$ & $\begin{array}{c}\text { mg./day } \\
\text { or } \\
m g . / 100 \mathrm{Gm} . *\end{array}$ & & days & $\%$ & $\%$ & \\
\hline \multicolumn{10}{|c|}{ Megaloblastic anemia } \\
\hline $\begin{array}{l}52 \\
53 \\
54 \\
55\end{array}$ & $\begin{array}{l}\mathrm{M} \\
\mathrm{M} \\
\mathrm{M} \\
\mathrm{F}\end{array}$ & $\begin{array}{l}62 \\
82 \\
65 \\
72\end{array}$ & $\begin{array}{c}161 \\
390^{*} \\
1,082^{*} \\
201\end{array}$ & $\begin{array}{c}18.6 \\
49.0^{*} \\
204.0^{*} \\
98.0\end{array}$ & $\begin{array}{l}8.6 \\
8.0 \\
5.3 \\
2.0\end{array}$ & $\begin{array}{l}20 \\
21\end{array}$ & $\begin{array}{r}6.0 \\
4.0 \\
13.0 \\
3.0\end{array}$ & $\begin{array}{l}37.2 \dagger \\
36.2 \dagger \\
38.0 \dagger \\
26.4 \dagger\end{array}$ & $\begin{array}{l}\text { Post-gastrectomy } \\
\text { Pernicious anemia } \\
\text { Pernicious anemia } \\
\text { Pernicious anemia }\end{array}$ \\
\hline \multicolumn{10}{|c|}{ Hyporegenerative anemia } \\
\hline $\begin{array}{l}56 \\
57 \\
58 \\
59 \\
60\end{array}$ & $\begin{array}{l}\mathrm{F} \\
\mathrm{M} \\
\mathrm{F} \\
\mathrm{F} \\
\mathrm{F}\end{array}$ & $\begin{array}{r}16 \\
6 \\
67 \\
42 \\
35\end{array}$ & $\begin{array}{l}13 \\
17 \\
108 \\
109 \\
17.2\left\{\begin{array}{l}7.8 \ddagger \\
18 \\
30\end{array}\right.\end{array}$ & $\begin{array}{l}0.66 \\
0.53 \\
5.8 \\
2.5 \\
3.03\end{array}\left\{\begin{array}{l}2.9 \\
2.2 \\
6.5\end{array}\right.$ & $\begin{array}{l}20.0 \\
32.1 \\
18.6 \\
43.6 \\
5.7\left\{\begin{array}{l}2.7 \\
8.2 \\
4.6\end{array}\right.\end{array}$ & 29 & $\begin{array}{l}1.5 \\
2.0 \\
0.5\end{array}$ & $\begin{array}{r}1.0 \\
25.8 \\
5.6\end{array}$ & Panmyelophthisis \\
\hline $\begin{array}{l}61 \\
62 \\
63 \\
64\end{array}$ & $\begin{array}{l}\mathrm{F} \\
\mathrm{F} \\
\mathrm{F} \\
\mathrm{M}\end{array}$ & $\begin{array}{l}17 \\
50 \\
50 \\
69\end{array}$ & $\begin{array}{l}40 \\
190 \\
135 \\
25^{*}\end{array}$ & $\begin{array}{c}3.0 \\
10.8 \\
16.8 \\
2.5^{*}\end{array}$ & $\begin{array}{r}13.3 \\
17.0 \\
8.0 \\
10.0\end{array}$ & $\begin{array}{l}14 \\
19\end{array}$ & $\begin{array}{c}0.5 \\
\text { Trace } \\
1.0 \\
2.0\end{array}$ & $\begin{array}{r}47.4 \\
33.0 \\
7.6 \\
2.4\end{array}$ & $\begin{array}{l}\text { Cong. hypopl. anemia } \\
\text { Atyp. myel. leukemia } \\
\text { Aleu. myel. leukemia } \\
\text { Atyp. myel. leukemia }\end{array}$ \\
\hline \multicolumn{10}{|c|}{ Anemia secondary to rheumatoid disease } \\
\hline 65 & $\mathbf{F}$ & 71 & $139\left\{\begin{array}{r}194 \\
85\end{array}\right.$ & $16.8\left\{\begin{array}{l}22.8 \\
10.8\end{array}\right.$ & $8.3\left\{\begin{array}{l}8.5 \\
7.9\end{array}\right.$ & 25 & & & \\
\hline $\begin{array}{l}66 \\
67 \\
68 \\
69 \\
70 \\
71 \\
72 \\
\end{array}$ & $\begin{array}{l}\mathrm{F} \\
\mathbf{M} \\
\mathbf{F} \\
\mathbf{F} \\
\mathbf{F} \\
\mathbf{M} \\
\mathbf{F}\end{array}$ & $\begin{array}{l}47 \\
54 \\
52 \\
47 \\
56 \\
43 \\
23 \\
\end{array}$ & $\begin{array}{c}50 \\
90 \\
30 \\
34 \\
19 \\
40 \\
160 \\
138^{*} \\
245^{*}\end{array}$ & $\begin{array}{l}8.5 \\
5.3 \\
2.6 \\
1.1 \\
0.66 \\
0.94 \\
22.7 \\
17.4^{*} \\
32.0^{*}\end{array}$ & $\begin{array}{r}6.0 \\
17.0 \\
11.5 \\
30.0 \\
29.0 \\
42.0 \\
7.0 \\
7.0 \\
7.7\end{array}$ & $\begin{array}{l}26.5 \\
25 \\
27\end{array}$ & $\begin{array}{r}1.5 \\
6.0 \\
15.0 \\
12.0 \\
17.0 \\
35.0 \\
\\
6.0\end{array}$ & $\begin{array}{l}40.6 \\
10.7 \\
32.4 \\
13.3 \\
50.6 \\
41.4 \\
\\
21.8\end{array}$ & \\
\hline 73 & $\mathbf{M}$ & 50 & $245^{*}$ & $32.0^{*}$ & 7.7 & & 6.0 & 21.8 & \\
\hline
\end{tabular}

* Numbers indicated by an asterisk denote quantitations in $\mathrm{mg}$. per $100 \mathrm{Gm}$.; numbers without an asterisk denote quantitations in $\mathrm{mg}$. per day.

$\dagger$ Erythrocyte precursors.
$\ddagger$ The values in brackets relate to determinations on individual four day collections for which the average is given at the left. 
small. The values for mesobilifuscin were generally elevated; in but one case (No. 33) was the $\mathrm{Mbf}$ within the normal range. Furthermore, the increase of $\mathrm{Mbf}$ was often relatively greater than the increase in urobilinogen. This was reflected by the $\mathrm{U} / \mathrm{Mbf}$ ratio which in 15 cases fell below the normal range. Statistical analysis of these data to determine the probability that 15 of 32 cases would have a $\mathrm{U} / \mathrm{Mbf}$ ratio less than 8.0 reveals that $\mathrm{p}<0.001$. The $\mathrm{T}_{1 / 2}$ of $\mathrm{Cr}^{51}$ was markedly shortened in five cases in which survival studies were performed. Normoblastic hyperplasia was apparent in all 18 cases in which bone marrow examinations were made. When therapy was effective in abolishing a hemolytic anemia, the values for $\mathrm{Mbf}$ fell to levels within or below the normal range and the $\mathrm{U} / \mathrm{Mbf}$ ratio rose to normal or above normal. Data from three cases
(Nos. 22, 30 and 43) illustrating this change are given in Table VIII.

A similar pattern of pigment excretion with a tendency toward increased urobilinogen, increased $\mathrm{Mbf}$ and normal or decreased $\mathrm{U} / \mathrm{Mbf}$ ratio is seen in megaloblastic anemia (Table IV, Figure 1). It has previously been shown that a large proportion of the fecal urobilinogen in this disease is derived from sources other than destruction of mature circulating red cells, perhaps by diversion of heme pigment or immediate precursors to production of bile pigment in the presence of ineffective heme synthesis $(13,15)$. The fecal Mbf was increased out of proportion to the increased urobilinogen. The U/Mbf ratio was markedly lowered in two and at the lower limit of normal in the other two cases. Red cell survival was slightly shortened, with the $\mathrm{T}_{1 / 2} \mathrm{Cr}^{51}$ being 20 and 21 days in

TABLE V

Urobilinogen and mesobilifuscin in the feces, $U / M b f$ ratio, erythrocyte survival and erythropoiesis in 27 patients with anemia due to other causes

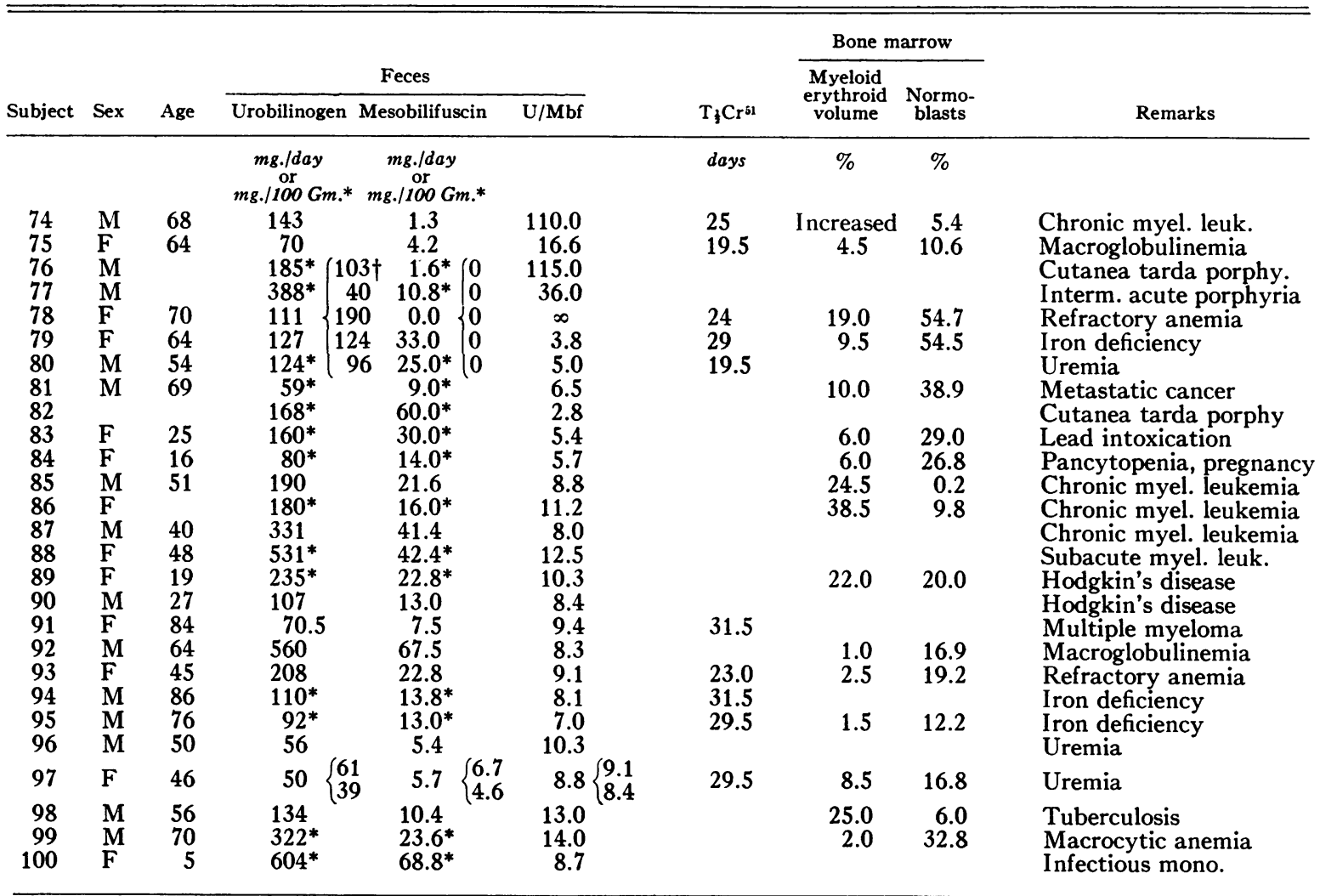

* Numbers indicated by an asterisk denote quantitations in $\mathrm{mg}$. per $100 \mathrm{Gm}$.; numbers without an asterisk denote quantitations in $\mathrm{mg}$. per day.

† The values in brackets relate to determinations on a series of four day collections for which the average value is given at the left. 
two patients studied; this appears to agree with earlier observations $(13,14)$ and with the findings of London and West using $\mathrm{N}^{15}$ (15).

Values for fecal Mbf in patients with hyporegenerative anemia (Table IV, Figure 1) differed remarkably both from the normal and from patients with hemolytic anemia and megaloblastic anemia. Seven of nine patients studied showed Mbf values which were well below the normal range. While fecal urobilinogen tended to be decreased in this group, it should be noted that four patients had normal urobilinogen values (either as a result of transfusion or hemolysis) and two of these had distinctly low Mbf values. Even in the presence of decreased urobilinogen, the $\mathrm{Mbf}$ was disproportionately low. The U/Mbf ratio was elevated in six cases; it was low in one patient (No. 60), the only one in whom significant variation was seen with multiple determinations. In Case 60 the Mbf was uniformly decreased, but the urobilinogen was disproportionately low to a varying degree. Subsequent studies of this remarkable case, to be described separately, have consistently shown an unexplained disappearance of bilirubin. One patient, E.H., a 42 year old woman with drug toxicity, was studied over a 24 day period. She presented the clinical picture of progressive bone marrow failure. Blood transfusions were given intermittently throughout this period. The results of this study are shown in Table IX. Despite fecal urobilinogen values in the normal range, the Mbf decreased with each successive four day period and finally disappeared in the last eight days.

The pigment excretion in patients with anemia secondary to rheumatoid disease (Table IV, Figure 1) was similar to that seen in hyporegenerative anemia. The fecal urobilinogen and $\mathrm{Mbf}$ were normal or decreased. The $\mathrm{U} / \mathrm{Mbf}$ ratio was normal or increased. Red cell survival was normal. Bone marrow studies, however, did not reveal reduced erythropoiesis. In fact, four of seven cases in which marrow studies were performed, manifested normoblastic hyperplasia. The possible significance of this is considered again in the following.

Table V includes data from 27 cases with anemia due to other causes. Fecal collections were

TABLE VI

Urobilinogen and mesobilifuscin in the feces, $U / M b f$ ratio, erythrocyte survival and erythropoiesis in 20 patients with parenchymal liver disease

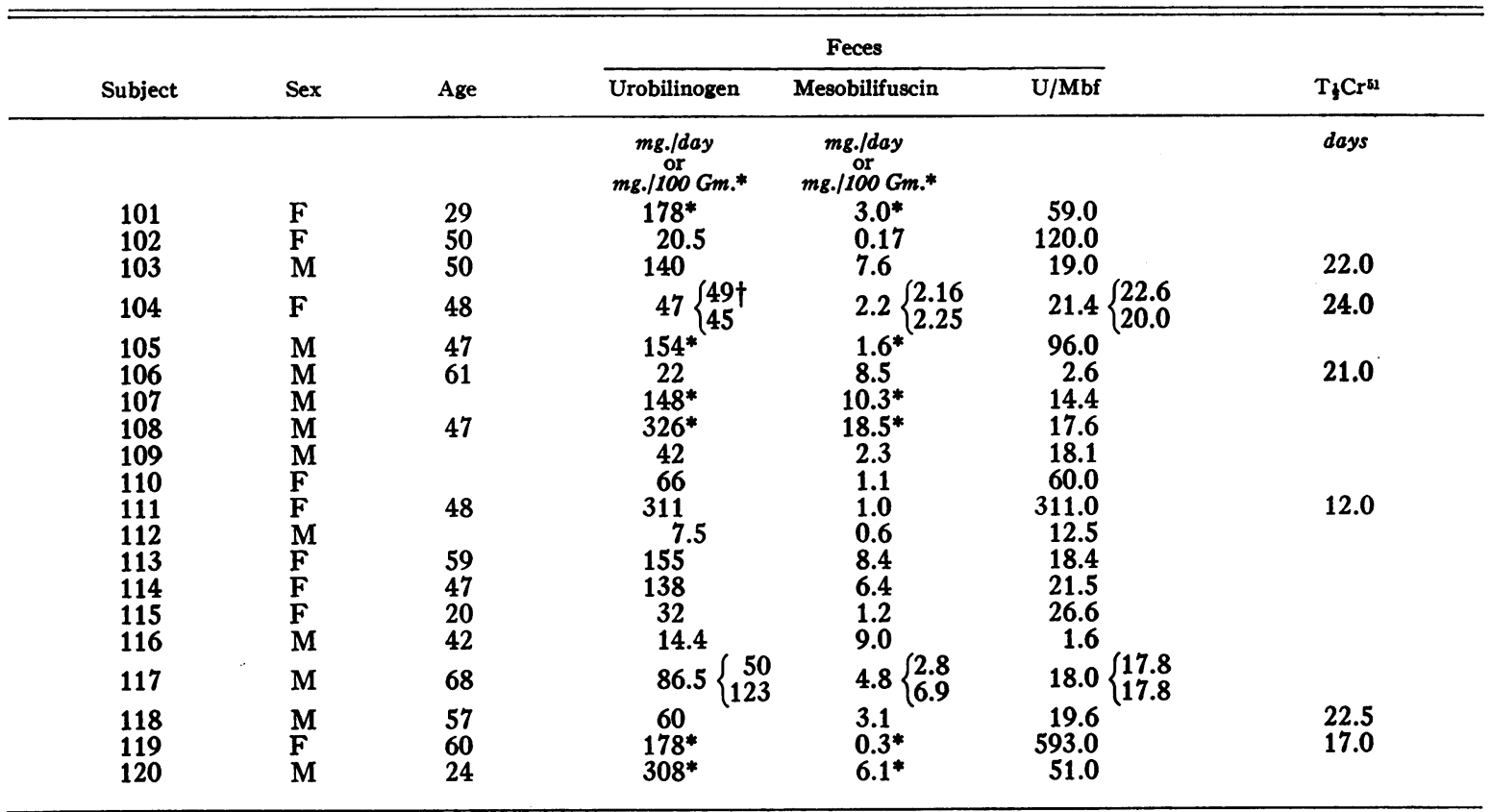

* Numbers indicated by an asterisk denote quantitations in $\mathrm{mg}$. per $100 \mathrm{Gm}$.; numbers without an asterisk denote quantitations in mg. per day.

$\dagger$ The values in brackets relate to individual four day collections for which the average is given at the left. 
adequate for per diem measurements in only 13 of this group. Nevertheless, the $\mathrm{U} / \mathrm{Mbf}$ ratio could be determined in all. The ratio was high in five patients (Nos. 74 through 78): of these two had normoblastic hypoplasia of the bone marrow; two had hepatic porphyria (one cutanea tarda and one intermittent acute); and one was a patient with refractory anemia in whom the bone marrow appeared hyperplastic. The urobilinogen values were normal in four of these five cases and borderline in one $(388 \mathrm{mg}$. per $100 \mathrm{Gm}$. feces). The U/Mbf ratio was low in six cases (Nos. 79 through 84 ). In all six the urobilinogen values were within the nomal range, and in the four cases in which bone marrow studies were done, normoblastic hyperplasia was present. The remaining 16 cases had normal U/Mbf ratios. Of the nine in which per diem measurements were possible, the fecal Mbf was normal in three, slightly decreased in two and slightly elevated in two. Bone marrow studies in four of the latter cases revealed normal or slightly reduced erythropoiesis. In two cases both Mbf and urobilinogen were markedly elevated (Nos. 87 and 92). The bone marrow was studied in one (No. 92) and appeared hypo-
TABLE VII

Urobilinogen and mesobilifuscin in the feces and $U / M b f$ ratio in 20 patients with biliary obstruction

\begin{tabular}{|c|c|c|c|c|c|}
\hline \multirow[b]{2}{*}{ Subject } & \multirow[b]{2}{*}{ Sex } & \multirow[b]{2}{*}{ Age } & \multicolumn{2}{|c|}{ Feces } & \multirow[b]{2}{*}{$\mathrm{U} / \mathrm{Mbf}$} \\
\hline & & & $\begin{array}{c}\text { Uro- } \\
\text { bilinogen }\end{array}$ & $\begin{array}{c}\text { Meso- } \\
\text { bilifuscin }\end{array}$ & \\
\hline & & & $\begin{array}{c}m g . / d a y \\
\text { or } \\
m g . / 100 \mathrm{Gm} . *\end{array}$ & $\begin{array}{c}m g . / d a y \\
m g . / 100 \mathrm{Gm} . *\end{array}$ & \\
\hline 121 & $\mathrm{~F}$ & & 0.24 & 0.0 & $\infty$ \\
\hline 122 & $\mathrm{~F}$ & 81 & $65.0^{*}$ & $7.6^{*}$ & 8.5 \\
\hline 123 & $\mathrm{~F}$ & 54 & 0.84 & 0.0 & $\infty$ \\
\hline 124 & $\mathrm{M}$ & 72 & 6.8 & 0.0 & $\infty$ \\
\hline 125 & M & & 0.16 & 0.0 & $\infty$ \\
\hline 126 & $\mathbf{F}$ & & 9.5 & 0.0 & $\infty$ \\
\hline 127 & $\mathbf{F}$ & & $6.0^{*}$ & $0.0^{*}$ & $\infty$ \\
\hline 128 & $\mathbf{M}$ & 59 & 3.7 & 0.21 & 17.6 \\
\hline 129 & $F$ & & 0.8 & 0.0 & $\infty$ \\
\hline 130 & $\mathbf{M}$ & & 6.5 & 0.0 & $\infty$ \\
\hline 131 & $\mathrm{~F}$ & & 8.6 & 0.0 & $\infty$ \\
\hline 132 & $\mathrm{~F}$ & 24 & 52.0 & 1.3 & 40.5 \\
\hline 133 & M & 75 & 1.3 & 0.0 & $\infty$ \\
\hline 134 & M & 75 & 115.0 & 12.8 & 9.0 \\
\hline 135 & $\mathrm{~F}$ & 67 & 1.02 & 0.0 & $\infty$ \\
\hline 136 & $\mathrm{~F}$ & & 13.0 & 0.4 & 33.0 \\
\hline 137 & $\mathrm{~F}$ & 4 mos. & $1.1^{*}$ & $0.0^{*}$ & $\infty$ \\
\hline 138 & $\mathrm{~F}$ & 4 mos. & $0.5^{*}$ & $0.0^{*}$ & $\infty$ \\
\hline 139 & M & & 3.9 & 0.0 & $\infty$ \\
\hline 140 & $\mathbf{M}$ & 65 & $2.7^{*}$ & $0.0^{*}$ & $\infty$ \\
\hline
\end{tabular}

* Numbers indicated by an asterisk denote quantitations in $\mathrm{mg}$. per $100 \mathrm{Gm}$.; numbers without an asterisk denote quantitations in $\mathrm{mg}$. per day.

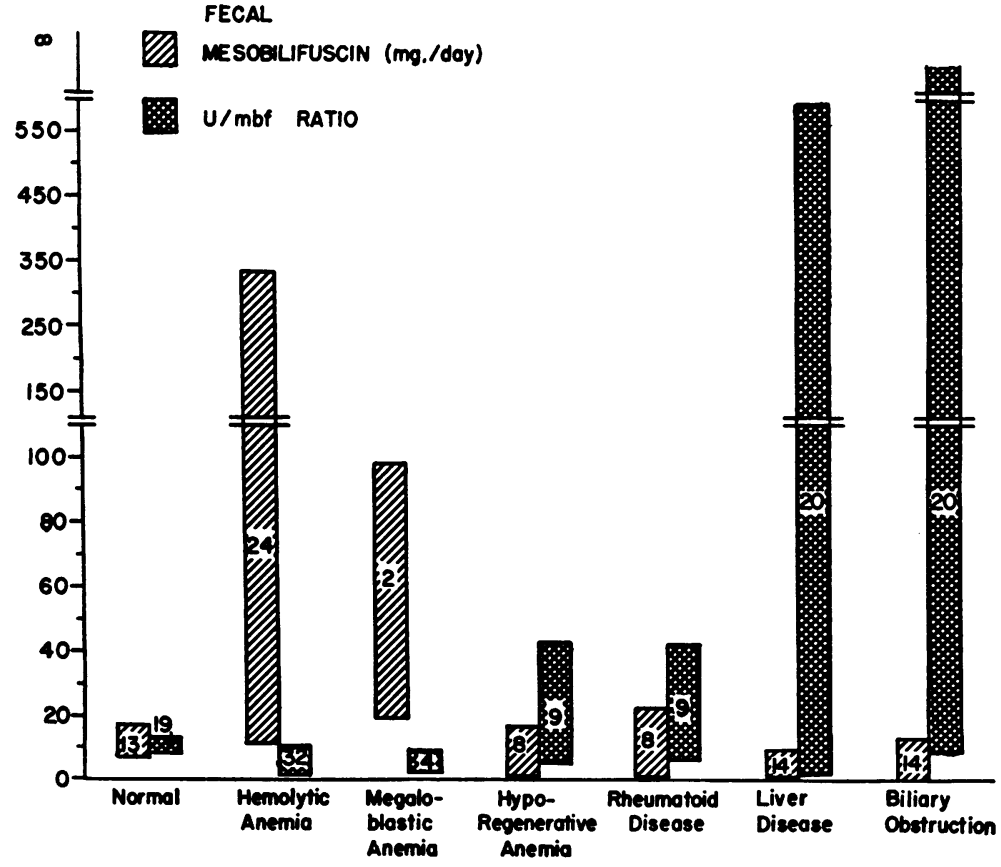

Fig. 1. Fecal Mesobilifuscin and U/Mbf Ratio in Normal Subjects and in Patients with Anemia

Numbers within the bars indicate the number of cases in each group. 
TABLE VIII

Change in fecal mesobilifuscin and $U / M b f$ ratio with treatment of hemolytic anemia

\begin{tabular}{|c|c|c|c|c|c|c|}
\hline Subject & Sex & Age & Time & Urobilinogen & Mesobilifuscin & $\mathrm{U} / \mathrm{Mbf}$ \\
\hline & & & & $\begin{array}{c}m g . / d a y \\
\text { or } \\
m g . / 100 \mathrm{Gm} .^{*}\end{array}$ & $\begin{array}{l}m g . / d a y \\
\text { or } \\
m g . / 100 \mathrm{Gm} .^{*}\end{array}$ & \\
\hline 22 & $\mathbf{M}$ & 57 & $\begin{array}{l}\text { Presplenectomy } \\
\text { Postsplenectomy } \\
1 \text { Year postsplenectomy }\end{array}$ & $\begin{array}{c}1,040^{*} \\
247 \\
124\end{array}$ & $\begin{array}{c}184.0^{*} \\
13.6 \\
13.9\end{array}$ & $\begin{array}{r}5.7 \\
17.5 \\
9.3\end{array}$ \\
\hline 30 & $\mathbf{F}$ & 25 & $\begin{array}{l}\text { Presplenectomy } \\
\text { Postsplenectomy }\end{array}$ & $\begin{array}{r}731 \\
30\end{array}$ & $\begin{array}{r}98.9 \\
3.4\end{array}$ & $\begin{array}{l}7.4 \\
9: 0\end{array}$ \\
\hline 43 & $\mathrm{~F}$ & 5 & $\begin{array}{l}\text { Pretreatment } \\
\text { Cortisone therapy }\end{array}$ & $\begin{array}{r}114 \\
43\end{array}$ & $\begin{array}{r}87.0 \\
4.0\end{array}$ & $\begin{array}{r}1.3 \\
11.0\end{array}$ \\
\hline
\end{tabular}

* See footnote to Table VII.

plastic; this will be considered again in the following.

In the presence of parenchymal liver disease (cirrhosis or hepatitis) the values for fecal Mbf were usually low, while the urobilinogen showed considerable variation. In the 20 patients in this series (Table VI, Figure 1) the values for fecal urobilinogen were within the normal range in eight, slightly elevated in three and decreased in nine. However, fifteen cases showed definitely reduced values for $\mathrm{Mbf}$ and three of the remainder were at the lower limit of the normal range. This disproportionate decrease of Mbf was reflected in the $\mathrm{U} / \mathrm{Mbf}$ ratio which was quite high in 17 cases. The U/Mbf ratio was normal in one case and definitely low in two. In the latter cases (Nos. 106 and 116) Mbf excretion was normal but urobilinogen was disproportionately decreased. Of interest are the red cell survival studies in six cases. The $\mathrm{T}_{1 / 2}$ of $\mathrm{Cr}^{51}$ was in the hemolytic range (12 days) in one patient (No. 84); uro-

TABLE IX

\begin{tabular}{|c|c|c|c|}
\hline \multirow[t]{2}{*}{ Time } & Urobilinogen & Mesobilifuscin & $\underset{\text { ratio }}{\mathbf{U} / \mathbf{M b f}}$ \\
\hline & $m g . / d a y$ & $m g . / d a y$ & \\
\hline $\begin{array}{l}10 / 20-23 \\
10 / 24-27 \\
10 / 28-31 \\
11 / 1-4 \\
11 / 5-8 \\
11 / 9-12\end{array}$ & $\begin{array}{r}103 \\
83 \\
64 \\
145 \\
91 \\
170\end{array}$ & $\begin{array}{l}5.7 \\
5.7 \\
2.5 \\
0.9 \\
0.0 \\
0.0\end{array}$ & $\begin{array}{c}18.1 \\
14.6 \\
25.6 \\
161.0 \\
\infty \\
\infty\end{array}$ \\
\hline
\end{tabular}

* The patient was a 42 year old woman. bilinogen was slightly elevated in this case (311 mg. per day), but Mbf was markedly decreased (1.0 mg. per day). In the other five cases the $\mathrm{T}_{1 / 2}$ of $\mathrm{Cr}^{51}$ was moderately shortened ( 17 to 24 days), but the urobilinogen was not elevated. These findings are in accord with the earlier study of Jones, Weinstein, Ettinger and Capps (16). In marked contrast to the decreased fecal excretion of $\mathrm{Mbf}$ was the finding of increased amounts of $\mathrm{Mbf}^{2}$ in the urine of 10 out of 11 patients as compared with seven normal subjects (Table X). Bilirubin was present in the urine of the three patients with the greatest values for mesobilifuscin (Nos. 111 through 113). In these cases it is not unlikely that some of the pigment was bilifuscin derived by oxidation of bilirubin. No bilirubin was detected in the urine of the other seven cases, three of which, however, exhibited excesses of urobilinogen.

Twenty patients with biliary obstruction were studied (Table VII, Figure 1). The fecal U/Mbf ratio was high in all but two of this group. In 11 the fecal urobilinogen value indicated complete biliary obstruction ( $<5 \mathrm{mg}$. per day) and in 10 of these no fecal Mbf was demonstrable; (Case $101 \mathrm{had} 3.7 \mathrm{mg}$. urobilinogen and $0.21 \mathrm{mg}$. Mbf per day). In nine cases there was incomplete biliary obstruction (urobilinogen $>5 \mathrm{mg}$. per day). In five of these no Mbf was demonstrated in the

2 Although obtained by the same adaptation of Siedel and Möller's (3) method as applied to feces, the material thus far analyzed is obviously impure and may be complexed with a non-nitrogenous urinary constituent, as the percentage of nitrogen ( 4.0 to 5.0 per cent) is less than the theoretical for Mbf ester, i.e., 8.8. 
feces, while in the other four small quantities were present.

\section{DISCUSSION}

Evidence described in the preceding paper (1), obtained by comparison of isotope labeled fecal stercobilin (or urobilin) and mesobilifuscin, after feeding $\mathrm{N}^{15}$ glycine, indicated that the latter is derived mainly from anabolic sources. The present data are in accord with that concept.

If the fecal Mbf were derived mainly from schism of bilirubinoid compounds as formerly postulated, one might anticipate that in different disease states the fecal urobilinogen and $\mathrm{Mbf}$ would vary in the same direction and to about the same degree. In other words, the U/Mbf ratio would be expected to remain essentially the same. Actually, as shown in the present study, the U/Mbf ratio varies greatly in different types of disease.

On the other hand, if the dipyrrylmethene pigments such as mesobilifuscin are derived mainly from anabolic sources, then their amount might often reflect the magnitude of heme synthesis. Thus, in hemolytic anemia, where red cell production is greatly enhanced, Mbf is also increased to a marked degree, often indeed to a relatively greater extent than the urobilinogen, so that the $\mathrm{U} / \mathrm{Mbf}$ ratio is low. Similarly in pernicious anemia, with its megaloblastic arrest in the bone marrow and ineffective heme synthesis (see above), the fecal Mbf is high and the $\mathrm{U} / \mathrm{Mbf}$ ratio low. This is not surprising in view of the observations mentioned previously, that in this disease a large proportion of the fecal urobilinogen is also derived from sources other than mature circulating red blood cells. In the hyporegenerative or "refractory" anemia, as a rule, very little fecal Mbf is found while the urobilinogen is often normal or increased, the latter being due either to a hemolytic factor, to blood transfusions, or both. Thus, the U/Mbf ratio is often high. A striking example of this is seen in Table IX. Observations in certain other cases of anemia (Table V) also support this concept. In most of these cases the rates of erythrocyte production and destruction are in balance. Thus, the $\mathrm{U} / \mathrm{Mbf}$ ratio is normal. Bone marrow studies in seven of the 11 cases with abnormal U/Mbf ratios show increased erythropoietic activity in all four cases with low $\mathrm{U} / \mathrm{Mbf}$
TABLE $X$

Excretion of urobilinogen, mesobilifuscin and bilirubin in the urine of normal subjects and patients with parenchymal liver disease

\begin{tabular}{|c|c|c|c|}
\hline Subject & Urobilinogen & Mesobilifuscin & Bilirubln \\
\hline & $m g . / d a y$ & $m g . / d a y$ & $m g . / d a y$ \\
\hline \multicolumn{4}{|c|}{ Normal subjects } \\
\hline $\begin{array}{r}4 \\
6 \\
10 \\
12 \\
13 \\
14 \\
15\end{array}$ & $\begin{array}{l}1.1 \\
1.4 \\
1.6 \\
0.6 \\
0.8 \\
1.8 \\
0.9\end{array}$ & $\begin{array}{l}1.2 \\
2.8 \\
3.0 \\
2.9 \\
1.8 \\
1.0 \\
1.8\end{array}$ & $\begin{array}{l}0 \\
0 \\
0 \\
0 \\
0 \\
0 \\
0\end{array}$ \\
\hline \multicolumn{4}{|c|}{ Parenchymal liver disease } \\
\hline $\begin{array}{l}107 \\
108 \\
109 \\
110 \\
111 \\
112 \\
113 \\
114 \\
115 \\
116 \\
117\end{array}$ & $\begin{array}{c}4.9 \\
6.0 \\
0.75 \\
0.2 \\
69.0 \\
5.4 \\
30.9 \\
0.2 \\
0.8 \\
1.2 \\
12.0\end{array}$ & $\begin{array}{r}18.9 \\
24.0 \\
6.5 \\
10.1 \\
60.1 \\
46.3 \\
40.0 \\
16.2 \\
12.9 \\
8.1 \\
1.4\end{array}$ & $\begin{array}{c}0 \\
0 \\
0 \\
0 \\
4+ \\
63.0 \\
16.2 \\
0 \\
0 \\
0 \\
\text { Not } \\
\text { determined }\end{array}$ \\
\hline
\end{tabular}

ratios and decreased erythropoietic activity in two cases with high $\mathrm{U} / \mathrm{Mbf}$ ratios. Several additional cases of anemia, not included in the Tables, have been studied recently. These have also shown a general parallelism between heme synthesis, erythropoiesis and Mbf excretion in the feces. Thus, the present data indicate that the magnitude of effective or attempted heme synthesis is more significant than hemoglobin destruction in determining the amount of fecal Mbf.

Exceptions to this rule are seen, however. In some cases $\mathrm{Mbf}$ is reduced and the $\mathrm{U} / \mathrm{Mbf}$ ratio is high, despite apparently normal or increased erythropoietic activity. Apart from the cases of liver and biliary tract disease, these findings have been encountered in patients with rheumatoid disease (Table IV, Figure 1), and in one patient (Case 78) with refractory anemia who had normoblastic hyperplasia of the bone marrow but no demonstrable $\mathrm{Mbf}$ in either feces or urine. In this situation one may consider the possibility that the immediate precursors of the dipyrrylmethene or "fuscin" compounds are being more efficiently utilized. It is conceivable that in association with an increased erythropoiesis, hemoglobin synthesis might proceed at a relatively slower rate but more efficiently 
so that no excess of precursors is available for Mbf formation. This would imply a more complete utilization in porphyrin synthesis, with little available for the excess dipyrrylmethene of the feces. The possibility might also be considered that some fraction of the fecal dipyrrylmethene, at least in some cases, is derived along the biosynthetic pathway to a heme other than that of the hemoglobin formed in the normoblast. It is true that in the two cases of hepatic porphyria (Nos. 76 and 77) the fecal Mbf was rather low, despite the strong likelihood that the metabolic disturbance in these cases is related to the biosynthesis of an hepatic heme or hemes, rather than hemoglobin. It is interesting to speculate that in this situation the excessive porphyrin and/or precursor formation might deplete the total "pigment pool" of the body to such an extent that Mbf elaboration related to hemoglobin synthesis might be significantly reduced. Nevertheless it is quite possible that under other abnormal circumstances there might be excessive dipyrrylmethene production unrelated to hemoglobin synthesis. In the case of lead poisoning (Case 83) with abnormal porphyrin synthesis, excessive amounts of fecal Mbf and a low $\mathrm{U} / \mathrm{Mbf}$ ratio were found.

In some cases conflicting results are found in the same disease state. Cases 96 and 97 with uremia show decreased fecal urobilinogen and $\mathrm{Mbf}$ and normal $\mathrm{U} / \mathrm{Mbf}$ ratios, while Case 80 , also uremia, shows increased fecal $\mathrm{Mbf}$ and a low $\mathrm{U} / \mathrm{Mbf}$ ratio. The latter patient had a moderately shortened red cell life span $\left(T_{1 / 2}\right.$ of $\mathrm{Cr}^{51}$ was 19.5 days) but a bone marrow biopsy was not done and unfortunately the per diem urobilinogen excretion was not determined. It is quite possible that a hemolytic element was important in this case.

In two cases of macroglobulinemia the findings are also at variance with each other. In one (No. 75) Mbf excretion was decreased and the $\mathrm{U} / \mathrm{Mbf}$ ratio was high, while in the other (No. 92) both urobilinogen and $\mathrm{Mbf}$ were definitely increased and the $\mathrm{U} / \mathrm{Mbf}$ ratio was normal. The bone marrow appeared hypoplastic in both. The basis of this difference is not clear.

Patients with liver disease usually excrete small amounts of fecal Mbf and exhibit high $\mathrm{U} / \mathrm{Mbf}$ ratios. The ratio may be low if the fecal urobilinogen is disproportionately reduced as in Cases 106 and 116 (see above). A likely explanation of the reduced fecal $\mathrm{Mbf}$ is that it cannot be excreted normally by a damaged liver and is diverted to the urine. This concept is supported by the consistent increases in urinary "mesobilifuscin" noted in Table X. At the same time, comparison of the data in Tables II, VI and X reveals that the total $\mathrm{Mbf}$ in urine and feces in the cases of hepatic disease is often considerably greater than that encountered normally. To what extent this increase is due to oxidative schism of bilirubin or urobilinogen, possibly in the kidney or urine, or to anabolic excesses, has not been determined.

\section{SUMMARY AND CONCLUSIONS}

1. The amounts of mesobilifuscin and urobilinogen in the feces have been compared in a group of normal subjects and in cases of various types of anemia and liver disease. The results in many of the cases were further compared with erythrocyte survival and erythropoiesis, with the aid of $\mathrm{Cr}^{51}$ and bone marrow studies.

2. The range of values for mesobilifuscin in normal human feces is 7 to $18 \mathrm{mg}$. per day and that for the urobilinogen/mesobilifuscin ( $\mathrm{U} / \mathrm{Mbf})$ ratio is 8 to 14 .

3. Conditions associated with increased erythropoietic activity, such as hemolytic and megaloblastic anemias, were generally associated with increased fecal mesobilifuscin (Mbf) and urobilinogen (U) and normal or low U/Mbf ratios. Conversely, cases of hyporegenerative anemia usually had decreased $\mathrm{Mbf}$ and high $\mathrm{U} / \mathrm{Mbf}$ ratios. This was also true in rheumatoid disease despite increased normoblastic activity in the bone marrow.

4. The observations summarized in Conclusion 3 accord better with the concept that the native fecal Mbf or its colorless chromogen is mainly anabolic, formed during the biosynthesis of heme, rather than a product of heme destruction and bilirubinoid schism.

5. In cases of liver disease, the fecal $\mathrm{Mbf}$ is disproportionately small and the $\mathrm{U} / \mathrm{Mbf}$ ratio high, while the urinary (crude) Mbf is consistently elevated. The extent to which the latter represents diversion of $\mathrm{Mbf}$ ordinarily excreted 
in the bile, or derivation from bilirubin or urobilinogen in the kidneys or urine, has not been determined.

\section{REFERENCES}

1. Gilbertsen, A. S., Lowry, P. T., Hawkinson, V., and Watson, C. J. Studies of the dipyrrylmethene ("fuscin") pigments. I. The anabolic significance of the fecal mesobilifuscin. J. clin. Invest. 1959, 38, 1166.

2. Schwartz, S., Sborov, V., and Watson, C. J. Studies of urobilinogen. IV. The quantitative determination of urobilinogen by means of the Evelyn photoelectric colorimeter. Amer. J. clin. Path. 1944, 14, 598.

3. Siedel, W., and Möller, H. Über Mesobilifuscin, ein neues physiologisches Abbauprodukt des Häms bzw. Hämatins. Z. physiol. Chem. 1939, 259, 113.

4. Read, R. C. Studies of red cell volume and turnover using radiochromium. Description of a new "closed" method of red-cell-volume measurement. New Engl. J. Med. 1954, 250, 1021.

5. Gray, S. J., and Sterling, K. The tagging of red cells and plasma proteins with radioactive chromium. J. clin. Invest. 1950, 29, 1604.

6. Ebaugh, F. G., Jr., Emerson, C. P., and Ross, J. F. The use of radioactive chromium ${ }^{51}$ as an erythrocyte tagging agent for the determination of red cell survival in vivo. J. clin. Invest. 1953, 32, 1260.

7. Necheles, T. F., Weinstein, I. M., and LeRoy, G. V. Radioactive sodium chromate for the study of survival of red blood cells. J. Lab. clin. Med. 1953, 42,358 .
8. Sundberg, R. D. Aspiration biopsy of bone marrow. Bull. U. Minn. Hosp. 1950, $21,471$.

9. Hawkinson, V., Watson, C. J., and Turner, R. H. A modification of Harrison's test for bilirubin in the urine, especially suited for mass and serial usage. J. Amer. med. Ass. 1945, 129, 514.

10. Malloy, H. T., and Evelyn, K. A. Oxidation method for bilirubin determinations in bile and meconium with photoelectric colorimeter. J. biol. Chem. 1937-1938, 122, 597.

11. Watson, C. J. Studies of urobilinogen. II. Urobilinogen in the urine and feces of subjects without evidence of disease of the liver or biliary tract. Arch. intern. Med. 1937, 59, 196.

12. Read, R. C., Wilson, G. M., and Gardner, F. H. The use of radioactive sodium chromate to evaluate the life span of the red blood cell in health and certain hematologic disorders. Amer. J. med. Sci. 1954, 228, 40.

13. Watson, C. J. The pyrrol pigments with particular reference to normal and pathologic hemoglobin metabolism in Downey's Handbook of Hematology. New York, P. Hoeber, 1938, vol. IV, p. 2447.

14. Watson, C. J. The Pyrrol Pigments and Hemoglobin Catabolism. The First E. T. Bell Lecture of the Minnesota Pathological Society. Minn. Med. 1956, 39, 294, 403 and 467.

15. London, I. M., and West, R. The formation of bile pigment in pernicious anemia. J. biol. Chem. 1950, 184, 359.

16. Jones, P. N., Weinstein, I. M., Ettinger, R. H., and Capps, R. B. Decreased red cell survival associated with liver disease: Use of radioactive sodium chromate in measurement of red cell survival. Arch. intern. Med. 1955, 95, 93. 